Roland Boer's five-volume work, On Marxism and Theology (2007-2013), explores the connections between Marxism and Christianity. In this interview, Boer speaks about some of the pressing issues and knotty questions raised in the series. Beginning with questions of Boer's intellectual and political formation, of previous work on the Marxism-Christianity link, and contemporary claims about the return of religion, the discussion moves to the treatment of religion by Marx and Engels, by key Second International thinkers, and within Russian Marxism. The interview then turns to the Western Marxist tradition and the importance of Ernst Bloch and Theodor Adorno in Boer's work. Responding to a final set of questions, Boer reflects on postsecularism and the new atheism, ethics and grace, and the contemporary struggle over the Christian legacy. 


\section{The Christian Question}

\section{ROLAND BOER with CHAMSY EL-OJEILI}

CHAMSY EL-OJEILI - Roland, before we get into the detail of your five-volume work, the Marxism and Theology series, I'd like to ask you some background questions. First, can you talk a little about your intellectual and political formation? What were the intellectual and political paths that led you towards On Marxism and Theology?

ROLAND BOER - A short answer would be that I followed, unwittingly at first, and far less illustriously, a path somewhat like that of Friedrich Engels. Like Engels, I was brought up in a Reformed (Calvinist) household, which provided a somewhat unconventional path to Marxism and then membership of the Communist party. In a little more detail: Engels grew up in Elberfeld, which is now a municipal subdivision of the city of Wuppertal, in a devoutly Calvinist family, and listened to many a sermon from the fabled Friedrich Wilhelm Krummacher. But he was always highly critical of the hypocrisy of his fellow church members, penning satirical pieces (under a pseudonym) on such practices. As he studied the new developments in philosophy and biblical criticism, he slowly and painfully lost his faith, as we find in the many letters written at the time. Not long afterwards, he would meet Marx and begin a lifelong collaboration. 
As for myself, perhaps I can put it this way: in the Reformed Calvinist tradition, there is a great emphasis on the critical use of reason, as well as on the need for the rulers of the day to follow divine imperatives; and, if aforesaid rulers refuse to do so, the people are perfectly justified in deposing the rulers. We might say that this type of insurrectionary theology is based on a radical transcendence. It is not for nothing that Calvinists were banned in countries like Denmark and France, where they were seen as dangerous revolutionaries who might lop off a royal head or two. This is a round-about way of saying there is something in the Reformed tradition that can-but does not necessarily_lead one to a Marxist position. As a footnote, this was also the experience of Kim Il Sung, the revolutionary founder of the Democratic People's Republic of Korea (informally known as North Korea).

CHAMSY - Can you say something about the predominant ways in which you encountered the Marxism-Christianity connection prior to deciding to write On Marxism and Theology? I am thinking, for instance, of the four major connections that I came upon as a young Marxist: first, Marxism understood as a key to understanding and overcoming religion-religion viewed as mere ruling-class ideology; second, Nietzsche's rejection of Christianity and socialism as resentful slave morality; third, the sceptical liberal contention that Marxism is essentially and dangerously theological; and fourth, the occasional, more appreciative attempts at a mutually respectful dialogue, such as Macintyre's Marxism and Christianity (1968) or McLellan's Marxism and Religion (1987).

ROLAND - Perhaps my answer here was already foreshadowed in my previous answer: it was through theology that I came to Marxism. Although I had left-ward political positions from my teens, my first real encounter with Marxism was in a course called 'Political and Liberation Theologies', as part of my bachelor of divinity studies (my second undergraduate degree) at the University of Sydney in the mid-1980s. We studied the MarxistChristian dialogue of the 1960s and 1970s in Europe, the development 
of political theology in that part of the world, and then the comparable development of liberation theology in Latin America.

My response to the course: I decided to study the works of Marx and Engels rather than read what others (theologians in this case) said about them. This is precisely what I did with my masters thesis, which focused on the theme of alienation and revolution in Hegel and Marx. From then on, I was hooked, so to speak. And until five or six years ago, I have examined a whole range of the complex intersections between Marxism and theology. These included deploying Marxist methods for biblical analysis, reconstructing the economies of the ancient world, and examining what European and Russian Marxists had to say about religion and theology. It was this final concern that led, from 2007, to a series of books on the topic.

CHAMSY - The books came out between 2007 and 2013. In this period, there's a fair bit of social and political commentary about the return of religion, clashing civilisations, and a post-secular turn in philosophy and theory. How did you read this commentary and what effect, if any, did it have on your project?

ROLAND - Believe it or not, it was rather peripheral to my main concerns. It may have functioned as a 'spirit of the times' influence, but I had already begun planning for the series of books back in 1992, when I was working for a brief time at the University of New England in Australia. I was struck, however, by how a few living Marxist critics, notably Alain Badiou, Slavoj Žižek, and Terry Eagleton, had shown a marked interest in Christian theology during that time. Only later did I realise what it signalled: a sense of the sunset of the Western project and a desire to return to its roots to see what it had contributed. For them, this was the very idea of revolution. I will have more to say about this point later.

CHAMSY - As a way of getting into some of the detail of these volumes, what were your hopes and aims for this work? One of the things that most struck me about these books, for instance, is their intimacy, your staging of 
close, warm, personal, 'live action'-feeling conversations with the thinkers you treat.

ROLAND - The project grew in the writing. I had initially planned one monograph, Criticism of Heaven. It grew and grew, with the completed manuscript numbering almost 275,000 words. In vain did I seek a publisher, for it was simply too long. Eventually, the Historical Materialism series (with Brill) agreed to publish it, but only if I 'shaved off 100,000 words. By then, I realised that much further study lay ahead of me, since I had already encountered indications of potential discoveries to be made.

The 'intimacy' of which you speak arose, I guess, from my preference for working closely with a text. The text became my interlocutor as I explored the insights and problems that arose. This approach is probably due to my training in Western classical languages (Greek, Latin, Sanskrit) and then a focus on biblical languages (Hebrew, Greek again, but also Syriac and Coptic). This training inculcated the principle to which I have stuck ever since: it is not possible to study a text without doing so in the original language. Much of the original material in the Marxism and Theology series is in German and some in French, although when I encountered Italian authors, I had to make an exception and work with translated material, fully aware of potential pitfalls.

CHAMSY - Perhaps we could begin getting our teeth into things by talking about Marx and Engels. Probably the first things that will come to mind for many people in thinking about Marx on religion is the famous quote from the introduction to the critique of Hegel's Philosophy of Right (1820), 'the opium of the people', and the notion that historical materialism entails viewing ideas as an efflux of material life. Perhaps, as well, readers might be familiar with Engels's Peasant War in Germany (1870), in which he draws attention to certain continuities between Christianity and socialism. Can you speak a little about the far more complicated approaches of Marx and Engels to religion in general, and to Christianity in particular? 
ROLAND - Let us begin with the famous 'opium of the people' quotation from a rather young Marx. The meaning is determined by the context in which it was used. Today, of course, we tend to have a rather negative view of opium, as a drug of addiction, dulling the senses, and causing early death. Perhaps its only ameliorating feature is as a palliative painkiller. Marx's $19^{\text {th }}$-century context was quite different: opium was seen as both a cheap medicine for poor workers and a potential curse, as a source of inspiration for artists and writers and as a cause of decline. The more positive view dominated earlier in the $19^{\text {th }}$ century, while the dangers of opium became more apparent towards the close of the century. In other words, when Marx deployed the metaphor in 1843, it was a very ambivalent one. I would add that Marx himself took opium as a medicine for his many ailments, from carbuncles, through tooth decay, to liver problems.

Now let us move to a rather different context, China, where I have been involved for a dozen years and have worked part-time for seven. Here, opium connotes colonialism, humiliation, and the need for liberation. It was the British who forced opium on China so as to empty the Chinese coffers of much of the gold and silver that it had accumulated from Latin American mines. How did the gold and silver arrive there? Europeans could not get enough of the fine wares from China and would pay with aforesaid gold and silver. Hence the forcing of opium on China, through a series of unequal treaties that included the seizure of Hong Kong by the British. To be added here is the fact the Christianity came to be seen as part of this whole process of humiliation. Christianity has been present in China for well over a millennium-Nestorians initially and then Roman Catholics somewhat later. However, the British used Hong Kong as a fulcrum to destabilise China, spreading opium further and trying to convert Chinese people to Christianity. In this light, Christianity is seen by most as 'foreign teaching', alien to Chinese culture and tradition. So when they read 'opium of the people' in Marx's text, it evokes these many-layered senses.

Let us return to Marx as a way to discuss Engels. As should be wellknown, in the same piece, Marx also speaks of religion being the sigh of the oppressed creature, a heart in a heartless world, and of religious 
suffering being at the same time the expression of, and protest against, real suffering. The 'opium of the people' obviously expresses a similar sense. In Engels's hands, this ambivalence over religion was much more political. As mentioned earlier, Engels grew up as a devout and believing Reformed (Calvinist) Christian, but gave up his faith after much struggle and pain in light of his study of new developments in philosophy, science, and theology. This experience would influence his later assessments of Christianity: he would often fulminate against the obscurantism and hypocrisy of religion, and of the way it was used to justify reactionary regimes and economic exploitation. At the same time, he became increasingly aware, already from his 20s, of another, more revolutionary dimension. I speak not of the fabled 'utopian socialism' that he and Marx would criticise in the Communist Manifesto (1848), but of the potential for a religion like Christianity to inspire revolutionary movements. Engels had already spoken of Wilhelm Weitling, who wrote The Poor Sinner's Gospel (1845), as the 'first German communist', but he would deploy this awareness to the full in his study of the 1525 Peasant Revolution led by Thomas Müntzer. The work does have its shortcomings, especially the argument that theology was a cloak or husk for a radical, non-theological message at its core, a message delivered to an inner circle. But it was the first historical-materialist interpretation of a crucial juncture in a tumultuous European $16^{\text {th }}$ century.

Engels was by no means finished with the theme. After a couple of articles in 1882 and 1883, he published just before his death On the History of Early Christianity (1894-1895). Engels admitted that he had been thinking about the core argument on and off for 40 years. Christianity was originally a revolutionary movement, appealing to the poor and to slaves, riven with factions and false prophets, and eventually turning the Roman Empire on its head. We might quibble that its very victory turned Christianity into its imperialist other, but the point had been made, with rather profound influence on religious and socialist circles in Germany and Europe.

CHAMSY - Similarly, it's very easy to assume a straightforward atheism, materialism, and consignment of Christianity to the dustbin of history 
in our imaginings of Second International orthodoxy. In what ways do Kautsky and Luxemburg, for instance, confirm or disconfirm this image?

ROLAND - At the same time that Engels was preparing his article on early Christianity for publication, Kautsky had published, as the lead author, a major two-volume 1895 work called Die Vorläufer des neueren Sozialismus (Forerunners of Modern Socialism). Running all the way from ancient Greece to their own time, the authors sought to trace the history of earlier revolutionary movements, most of them inspired by Christianity. Kautsky wrote the bulk of the material concerning earlier movements through to the $16^{\text {th }}$ century. Here, he coined the term 'Christian communism', based as it was, he argued, on the practice of communal life, drawn from many biblical texts, but especially the 'all things in common' from the Book of Acts, chapters 2 and 4. Further, Kautsky argued that this Christian communism was a communism of consumption rather than production; it required all members to give of what they had so that it could be shared equally among all. All very well, suggests Kautsky, but when the goods ran out, members would have to go out to work for more. Far better to change the means of production, as modern socialism proposed. This was, by and large, the same argument propounded in Rosa Luxemburg's 'Socialism and the Churches' (1905). The difference is that Luxemburg's pamphlet explicitly targets Christian workers, who had joined the German Social Democrats in large numbers. Warned by their priests and ministers against 'evil' and 'atheistic' communism, Luxemburg seeks to assure these workers that communism is nothing of the sort. The modern party's revolutionary socialism could already be found, in some respects, in earliest Christianity.

Kautsky's treatment of early Christianity in this work was relatively brief, but evinced at least two responses. One was from a rather surprised Engels, who had not been informed of the work's development. Initially disappointed that he had not been approached, Engels also gave the work his blessing. The other response came from a battery of religious leaders and theologians, as well as not a few socialists. This critical response led to the full study of 1908, Foundations of Christianity. 
However, my favourite part of Forerunners of Modern Socialism is the material on the $16^{\text {th }}$ century. While Kautsky usefully outlines the history of Christian-communist movements through the European Middle Ages, his most careful and detailed studies are of the Peasant Revolution of 1525 and the Anabaptist Revolution based in the city of Münster in 1534-1535. I cannot go into too much detail here, but would like to note the following points. First, Kautsky skilfully assesses the bias of his sources, noting that they are almost all hostile, apart from the surviving texts from Müntzer's own hand. Second, Kautsky identifies two overlapping features of these movements: the enactment of communist forms of living, usually in small communities and away from persecution, and the need for revolutionary action, especially when the community was threatened, but also when it was felt that nothing could be done without more systemic change to the whole system. Third, Kautsky broaches the argument that Christian theology was not merely an outer husk, a language, for such revolutionary movements, but that there is something within Christianity itself that gives rise to them.

With all of this material, we are left with a question: is modern socialism (Marxism) merely a continuation in another form, or is it distinct? Engels may have emphasised the scientific nature of modern socialism, but for Kautsky the difference had more to do with the need to revolutionise the means of production as a whole, for systemic change, rather than localised revolts or small groups seeking to enact communist modes of living. This approach, he argued, was the distinct contribution of Marxism.

CHAMSY - Same question with Russian Marxism, Plekhanov and Lenin, say. Could you also speak about the particularities of the Russian context and of the Eastern orthodoxy as shaping the responses of Russian Marxists, and could you reflect on some of the significant landmarks in Soviet policy on religion?

ROLAND - Perhaps it would be better to speak of Lenin and Stalin, partly because I have not studied Plekhanov in depth. As for Lenin, his default 
position was that religion really had no place in a revolutionary communist party. By and large, he saw religion as obscurantism, befuddling the masses and supporting the autocracy. Thus, when he was forced to deal with the 'religious question', we find him struggling to come to terms with another reality. Let me give two examples. The first concerns a series of articles on the 'religious question'. Lenin knew full well that the international communist movement's approach to religion was to leave it as a 'matter of conscience', as the Erfurt Program of 1892 put it. If a religious worker wished to join the party and could agree to its platform, then this worker was welcome. But, argued Lenin, this worker must seek neither to propagate religious beliefs among party members, nor to agitate for changes to the program. And if a particular feature of the program challenged the aforesaid worker's beliefs, then it was up to the worker to sort this out.

The second example concerns one of my favourite Russian revolutionaries, Anatoly Lunacharsky, who was made commissar for enlightenment after the October Revolution. Earlier, Lunacharsky had penned a two-volume work called Religion and Socialism (1908 and 1911, untranslated). He had studied all of the material published thus far, including that of Kautsky, but he also went further. Not only was he enamoured with the biblical prophets, Jesus of Nazareth and the Apostle Paul, but he also proposed that religion expresses the ideal to which humanity strives. The gods express this ideal, compared to which human beings are rough ingots waiting to be shaped and sculpted. We would be mistaken if we think that Lunacharsky was pursuing a type of secular deification of human beings, or even of human leaders (personality cult). Instead, Lunacharsky saw the role of education, the arts, and government policy in this light, so much so that when he led the reshaping of the education system after the October Revolution, this theme was its theoretical justification. How was the earlier argument of Lunacharsky received by Lenin and the other comrades? They were profoundly suspicious, with Lenin writing Materialism and EmpirioCriticism (1908) partly as a response to the first volume of Lunacharsky's Religion and Socialism. Even more, Lunacharsky found he needed to recant this earlier work, with the result that it did not appear in his later 
Collected Works. Clearly, this type of material was mostly marginalised in the Russian Revolution, so that Lunacharsky found he had to promote his ideas concerning education and the arts without overt reference to religion.

When we turn to the question of religious policy, we find a somewhat different and more pragmatic approach. Lenin may have voiced occasional admiration for peasant wisdom expressed in religious terms, and he may have admired religious sectarians like the Old Believers for their discipline and communal practices, but the real policy decisions were made under Stalin's tenure. This may come as a surprise to some, but Stalin's five years of theological education at the Spiritual Seminary in Tiflis, Georgia, meant that he had a finely attuned theological ear. All of this came to the fore with the famous concordat between the government and the Russian Orthodox church in 1943. Back in 1936, Stalin had already insisted on the article concerning religious freedom being included in the Soviet Constitution. In the same constitution he had ensured that two biblical texts would appear: first, the one who does not wish to work shall not eat, from 2 Thessalonians 3:10; and second, a definition of socialism as from each according to ability and to each according to work, a complex gloss on Acts 2 and 4, thus distinguishing socialism from communism's 'to each according to need. Meanwhile, Sergei, the man who would become the next patriarch (primate of the self-ruling Russian Orthodox church), had already begun work from 1927 to seek rapprochement with the Bolsheviks. Sergei sought to re-establish the church's jurisdiction, asserted strenuously the rights stated in the 1936 constitution, and, when war broke out in 1941, made it very clear on whose side the church would fight. By 1943, the time was ripe for a meeting, and in the early hours of a September morning he and two other church leaders met with Stalin. The outcome was a momentous concordat that enabled the Holy Synod to be reconvened and Sergei to be elected patriarch. Over time, thousands of churches, monasteries, and theological colleges were reopened. Stalin kept a close watch on developments, corresponding regularly with Sergei and his successor Aleksii. We should not be surprised that they regularly addressed Stalin as a 'deeply revered, wise, divinely appointed leader' due to his 'constant, wise attention to Her 
[the Church's] needs'. The concordat lasted for ten years, until Stalin's death. His brief successor, Khrushchev, reverted most of these achievements and resumed persecution of the church.

CHAMSY - Perry Anderson famously designates Western Marxism as a mutation that occurs within Marxism in response to a bunch of reality problems, and one that moves in a more pessimistic, philosophical, distanced, and cultural series of directions in responding to these problems, particularly defeat. Clearly, the thinkers within Western Marxism are important interlocutors for you. Can you talk about whether we can make any general statements about Western Marxism and Christianity? What are some of the notable contributions, aside from Adorno and Bloch, who we will turn to focus on later?

ROLAND - In some respects Anderson is correct, especially in terms of the fact that Western Marxism had never experienced a successful revolution and been unable to exercise power so as to construct socialism. This puts Western Marxism in a unique and anomalous position, compared to the Marxisms of Latin America, Eastern Europe, Russia, and Asia. And it does entail a retreat from, and even abandonment of, the organisation of a revolutionary workers' party (Alain Badiou is a good example). Domenico Losurdo has also argued, in his last work (Il marxismo occidentale, 2017), that Western Marxism is an aberration, although the reasons he adduces are a little different. Losurdo attributes part of Western Marxism's development to the influence of religion, which has led to a 'utopian' and 'messianic' proclivity, as well as to suspicions of science and of the role of the state. Let us stay with the religious dimension: the way I interpret Losurdo's argument is that there is always a danger of a type of passivism in religious answers. If God is the answer, and if qualitative social and personal change can take place only through divine intervention, then one may as well sit back and wait for this to happen. At times, we find Western Marxists falling into this trap, awaiting an 'event' that is unexpected and unknowable, that cannot be calculated by any means available to us. The revolution will come like a 
thief in the night, taking us unawares and changing all before we know it.

This type of passivism, with its messianic or eschatological answer, is a distinct sign of defeat, but it is also a distortion of a crucial dialectic. Let me put it this way: so often, revolutionary religious movements have a theological inspiration that is based on a high sense of transcendence. How so? All human beings, especially rulers, are subject to the laws of God. Should a ruler disobey, then that ruler should be removed. And in many cases it was precisely the revolutionaries who saw themselves in such a role. In other words, a high or radical transcendence is not a motivation to passivism, but to engaged action. We can also put this in specifically Marxist terms as a dialectic of objective conditions and subjective intervention. A communist party must assiduously study the situation in question and attempt to discern the objective economic and social conditions. However, these conditions will not change in and of themselves, for such qualitative and revolutionary change requires the active intervention of a communist party to bring about the change in question. Unfortunately, and after a history of earlier defeats, many Western Marxists seem to have forgotten this dialectic.

How does all this relate to the renewed interest in religion, but especially Christianity, in the late 1990s and then the 2000s? Part of this process was due to the perceived 'failure' of communism as the socialist states of Eastern Europe and the Soviet Union imploded and were colonised in many cases by the West. East Germany is the best example, but consider also the roles of other eastern European countries in NATO and the EU. 1989 led to significant soul-searching among many Western Marxists, with one result being a return to Christian history and a desire to find an alternative model for revolution. Another part of this process was what I called the 'sunset of the West'. This sunset already began in the 1990s, at the very moment of the apparent victory of the West. Few may have been aware of it then (it is unavoidable now), but there were premonitions. One of these was a turn by some Western Marxists to rediscover a legacy worth fighting for, namely, Christianity. More specifically, this legacy was seen to be the revolutionary dimension of Christianity, which could then be recovered and shown to the 
world as a unique contribution of the Western tradition.

The way I have put this indicates my scepticism towards the agenda. I find that those who have more clearly promoted this approach enthuse me less. By contrast, those who perhaps came earlier or did not fall into this type of Marxist agenda enthuse me more, especially Ernst Bloch, Theodor Adorno, and Domenico Losurdo.

CHAMSY - When I read Bloch's The Principle of Hope (1954-1959), I was really surprised by his warmth about Christianity. Can you talk a little about Bloch's approach, including questions of utopia and myth? Perhaps this is a good place, too, to discuss your scepticism about the myth of early Christian communism. You find this, for instance, in John Dominic Crossan's work on Jesus, Paul, and early Christianity. I find this very compelling. What are your hesitations about such lines of thought?

ROLAND - My first encounter with Bloch was in the early 1980s, when I read Atheism in Christianity (1968) on a university commute by train in Sydney. I was both puzzled and immensely drawn to Bloch. Puzzled because of his distinct style, but also drawn because it invited me to become much more familiar with his work. Since then, I have studied Bloch in detail and still return to his work when I need to think through a particular problem. I must admit that I was initially drawn to Bloch due to the suspicion with which he was, and is, held by more mechanical Marxists. Too much philosophy, too much reclaiming of myth and especially Christianity and the Bible; the latter is one of his major inspirations for The Principle of Hope, let alone the rest of his work.

The appeal for me is that Bloch is a great exponent of Marxist dialectics. He is certainly not in favour of dispensing with all myth, all religious texts, and all theological expression; this, he argues, would be undialectical. Instead, we need a 'hermeneutics of hope', in which the regressive and reactionary elements of, say, biblical myth and narrative are identified as such. At the same time, we need not merely identify the revolutionary elements of such material, but discern the very possibility of 
hope within the reactionary material. An excellent example is his approach to stories of rebellion, and indeed sin, against the powers that be and thus the deity. Inevitably, the stories recount how the rebels are punished for their impertinence, but the very act of telling such stories preserves the moment of rebellion. This approach means that Bloch seeks what he calls the 'utopian' drive in marginal and heretical expressions, rather than in the mainstream expressions of the text. Not all theologians would agree, for those who seek socialist precursors tend to prefer the mainstream, canonical texts. And certainly not all Marxists have been enthused, missing the subtlety of Bloch's dialectic and finding his theological and biblical engagements unpalatable.

All of this brings me to early Christian communism, concerning which I have changed my mind. Initially, I was somewhat sceptical, seeing the material as a 'utopian' desire for what might be, but was not actually practised. In this light, the biblical texts, and others from the time, such as those from Qumran, reflect not a genuine movement at the time but produced a concrete movement in their wake, as one group after another attempted to live up to the biblical stipulations. Why have I changed my mind? Much has to do with studying the work of Engels more systematically, but also returning to study Kautsky in more depth, especially Forerunners of Modern Socialism. Other work on economic modelling of the Ancient Near East and the Greco-Roman world, especially what is known as the basic system of collective 'subsistence-survival' among peasant populations, has led me to realise that the exercise of Christian communism was by no means an innovation, but actually a manifestation of a much older practice that is best called 'baseline communism'.

CHAMSY - Theodor Adorno is also important for you, in your scepticism about system-building, and also what you call the practice of theological suspicion. Can you talk a little about this influence?

ROLAND - In one respect, Adorno is a resolute 'Western' Marxist, with his assumption of the universality of the capitalist system and his dismissal of 
actual communist revolutions in Eastern Europe and Russia and their efforts to construct socialism from a relatively 'backward' economic situation. At the same time, I have been drawn to Adorno's efforts to develop what I called 'theological suspicion'. It is part of his larger project of the Bilderverbot, or 'ban on images', which he draws from the Ten Commandments and the biblical tradition. For Adorno, this meant the search for a non-conceptual philosophy and his aversion to system-building. Crucially, one should include this very practice in every philosophical step, being always alert for the possibility of reified concepts. This approach can also be seen when he engages with theology, which he saw, through the Bilderverbot, as having developed a refined suspicion of reification. Of course, Christian theology has constantly fallen into what Adorno sees as the trap of trying to represent the divine, predict the end of history, or anticipate heaven. But all of these expressions are made with poetic and mythological language, being careful indeed to avoid prescriptions or blueprints.

I should also say that I do not return to Adorno so much today. Part of the reason is that I have become more aware of how 'Western' his approach really is, which means that it may be appropriate for those parts of the world influenced by the Western liberal tradition, but not really so applicable to the majority of other places that are not so influenced and do not ascribe to this tradition.

CHAMSY - I mentioned earlier the so-called post-secular turn in social theory and philosophy. As framed by Gregor McLennan, a major sceptic about this turn, post-secularism entails a growing willingness to seek to bridge the religion-secular social-theory divide, which he sees as a legacy of the postmodern turn. McLennan ultimately insists on irresolvable epistemological and ethical tensions separating Marxism and religious worldviews. I wonder how you would respond. On a related but incongruent note, while we have this commentary on the unsecularisation of the world and post-secular tendencies within the human sciences, we see, in the same period, the appearance of a so-called new atheism, most visibly, with interventions from Richard Dawkins and Christopher Hitchens. I would 
be very interested in what you make of the new atheism.

ROLAND - Let me begin my reply as follows: in the 1980s, I had photocopied a significant amount of material concerning the MarxistChristian dialogue, which flourished in Europe in the 1970s. I had deployed some of this material for my master's thesis on Hegel and Marx, but for some reason kept it in a large folder. Finally, I returned to it a couple of years ago, when I was writing a chapter on this Marxist-Christian dialogue for a monograph called Red Theology (2019). I was struck by the way that a major question in the dialogue was precisely this epistemological question of a/theism. At the same time, it seemed like a red herring. Why? All of the research I had undertaken on Marxism and theology was on Marxist thinkers who were atheists, or had given up a youthful faith (Engels, Althusser, and Lefebvre, for example). Almost uniformly, they did not see the question of theism or atheism as a problem; indeed, their atheistic positions did not prevent them from delving into the complexities of theological debate and biblical analysis. Of course, you do find moments-Engels in Socialism: Utopian and Scientific (1880) and Lenin's curious Materialism and EmpirioCriticism - where such epistemological points are made. But they were also fully aware that to take up the cudgel to attack religion would involve aligning with a bourgeois agenda and splitting the working class.

By now my response to the 'new atheists' should be clear. This is ultimately a bourgeois project, but it is also strikingly unoriginal. It reminds us of the initial developments of the secular movement in the $19^{\text {th }}$ century, when the relatively new movement had heated debates over their response to religion. Some felt (George Holyoake being the most prominent) that religion was a secondary matter; others, however, argued strongly that the secular movement should make religion, and especially the relations between church and state, central to their project. It was these people who won out.

More recently, I have become aware that the whole post-secular-neoatheist division is a distinctly Western phenomenon, with its own particular history. I will return to this point in reply to the next two questions, but here 
the relevant point is that the very history of entwinement of church and state, their gradual process of separation beginning with the Reformation and coming to the fore with a series of bourgeois revolutions, and then the post-secular turn, is a distinctly Western historical trajectory.

CHAMSY - Part of this post-secular trend in social theory involves a range of Marxian figures, Negri, Eagleton, Badiou, and Žižek, who both seek a retrieval of Marxism and attempt to draw from Christian sources in accomplishing this. What do you make of this work? It seems, as well, that you lean strongly away from a Catholic Marxism of ethics/love (the realm of moralising, in-place customs and habits, 'oiling relations so that they work more smoothly') and towards a Protestant Marxism of politics/grace ('the miraculous intrusion of the radically other', as Sharpe characterises it). ${ }^{1}$ Is this a fair characterisation of your conversations with these thinkers?

ROLAND - In hindsight, it seems to me now that these engagements by Marxists with Christian sources, particularly in the first decade of the $20^{\text {th }}$ century, indicate that it was not so much Western Marxism that faced a crisis after 1989 (which many felt, at least in the 1990s), but the Western project as such. By the early years of the current millennium, the project began to show clear signs of fraying. Minds began to close, borders were tightened, the outside world became a more fearful place, if not a threat. I experienced this in one Western country after another and was at the time puzzled and dismayed. At one point, I tried to understand these developments in terms of the West 'losing its soul'. By this I meant that the crucial role of Christianity in the development of the West, which really began to rise in the $16^{\text {th }}$ century, its liberal tradition, capitalism, and the capitalist state. The catch was, and still is, that by far the majority of people grant Christianity no more than lip service. Where to find this soul? For these Marxists and others, it was to rediscover a revolutionary core to

1 Roland Boer, In the Vale of Tears: On Marxism and Theology (Leiden: Brill, 2013), 245; Matthew Sharpe, 'On Roland Boer's Marxism and Theology,' Critical Research on Religion 4, no. 2 (2016): 177. 
Christianity, which could be seen as the West's distinctive contribution. I know I have mentioned this point earlier, but have now been able to elaborate a little further.

In regard to politics/grace in contrast to ethics/love, this was really due to my own rediscovery of the importance of the Reformed (Calvinist) tradition for my formation. I had been brought up in this tradition by my immigrant parents and even wrote a book on Calvin in time for the $500^{\text {th }}$ anniversary. Obviously, this personal intellectual rediscovery influenced my reading of Western Marxists at the time.

CHAMSY - Finally, I think your work is additionally vital given a major contemporary battle for the heart of Christianity. On the one side, we are clearly seeing a major pole of attraction developing that seeks a more progressive reading of the New Testament, articulated in thinkers like Marcus Borg and Crossan. At the same time, elements of today's far right also want to use the Bible for their mobilising passions. I say 'elements' because there are other, quite different spiritual resources often drawn on by this Right - for instance, the paganism championed by the French Nouvelle Droit. But elsewhere, for example, Polish Law and Justice, the AfD, Lega, appeals to Christian tradition have become a part of the farright counter-movement to 'cultural Marxism', globalism, feminism, political correctness, and multiculturalism. Do you have any observations around this? And perhaps, to close, what might be the possible futures of the Marxist-Christian dialogue that you have so beautifully and thoughtfully presented?

ROLAND - The first part of my previous reply is relevant here too, so I will not return to the question of the sunset of the West. Instead, let me emphasise that the struggle over the Christian legacy, in either a reactionary or a revolutionary direction, is nothing new. If you look back over the history of Christianity, you find these tendencies appearing at many instances, albeit in different articulations. Think of early Christian communism and the religion of Empire under Constantine, the rise in 
revolutionary movements during and after the Reformation and the rise of absolute monarchy, or the struggle between liberation theology and a conservative Church hierarchy. The list could go on. My point: it is not so much a struggle over the heart of Christianity, even though it is often framed in this way, but rather that there is a curious political ambivalence in Christian thought and practice. The Bible, as Ernst Bloch put it, is not only folly to the rich but can also be a scandal to the poor.

Finally, in relation to the future of Marxist-Christian dialogue, I am wary of making projections. That there is a struggle under way concerning Christianity and its legacy is a sign of crisis, by no means the first that the West has faced. In the past, such struggles have had an outcome in which the West was able to maintain its imperialist and cultural dominance on the globe. These days, I am not so sure this will be the result. Western countries number relatively few, with only 14 percent of the world's population, and their dominance has been relatively brief in terms of world history. But perhaps the most important reality is that there are far more Christians now in non-Western countries. Their influence will become increasingly vital. 